\title{
Adults' Representations of Balinese Universal Quantifiers
}

\author{
I Nyoman Aryawibawa \\ English Department, Udayana University \\ Denpasar, Indonesia \\ arya_wibawa@unud.ac.id
}

\begin{abstract}
Balinese universal quantifiers have not been explored, particularly, by Indonesian scholars. The main purpose of current study is to investigate how Balinese adults represent the meanings of universal quantifiers in Balinese. The study employed picture selection tasks and involved thirty-seven Balinese undergraduate students at the Udayana University. The picture selection tasks basically require that the participants match a Balinese sentence containing a distributive or collective quantifier to stimuli consisting three pictures depicting events with universal quantifiers. The findings show that the participants can separate the distributive meaning of sebilang 'every/each' (e.g., sebilang anak cerike ento ngisi bal 'every child is carrying a ball') from the collective meaning of makejang 'all' (e.g., makejang anak cerike ento ngisi bal 'all the children are carrying a ball'). Specifically, $76 \%$ of the participants assigned canonical distributive and collective meanings to each/every and all respectively, while $24 \%$ of them assigned the meanings noncanonically (i.e., the collective meaning was represented to each/every, while the distributive meaning was represented to all). The later figure seems to relate to the possible ambiguous nature of Balinese universal quantifiers. In short, the results of current study suggest that the adults are able to distinguish the distributive meaning from the collective one in using Balinese universal quantifiers. The results, however, need further testing to children to find out if they are able to represent the meanings canonically as well.
\end{abstract}

Keywords-acquisition; universal quantifier; distributive meaning; collective meaning

\section{INTRODUCTION}

Scholars are still debating on the issue that language is indeed universal. There have been many linguistic issues that have been systematically explored to answer the claim. One prominent issue that has been widely addressed for the purpose is in the field of spatial semantics. In the field, there is a strong claim that the relative spatial system is claimed to be innate or universal in nature. The claim, however, seems not to be confirmed. Many languages (e.g. Balinese) does not share the system. Instead, the language employs the absolute system. In systematic studies of Balinese spatial systems by Aryawibawa (2010) and Aryawibawa et al. (2018, submitted), the results show that Balinese uses the absolute system dominantly.

There is also a language (e.g. Kuuk Thaayorre) that has not only a spatial aspect that is distinct from other languages, but also its temporal aspect is different from other languages as reported by Boroditsky (2011). In the language, the cardinal terms such as the north/east/west/south is practiced in temporal related tasks (e.g. rearrangement of shuffled photos of physical development of a crocodile) as reflection of the practice in their spatial orientations (e.g. the cup is north of the plate) as summarized in Aryawibawa (2018).

The efforts of testing that language is universal have also been conducted in the field of universal quantifiers as aimed in the current study. Specifically, the present study is specifically aimed to confirm that the meanings of the universal quantifiers are innate/universal. The language investigated for the purpose is Balinese.

\section{LITERATURE REVIEW}

Vendler (1967) explains basic representations of universal quantifiers in English (i.e., all, each, every). The first representation is called collective. The collective representation means that a predicate is applicable to all members of a group as exemplified in All the children are riding $a$ horse. The sentence entails the meaning that all the children are riding the same horse. The second representation is termed distributive where the predicate is applicable to each member of a group as in Each child is riding a horse. The sentence has the meaning that each child is riding a different horse.

Ioup (1975) also shows that other fourteen languages have the same basic representation of universal quantifiers as those in English as well. The two studies claim that the representations are innate in nature as further supported by (Brooks and Braine, 1996; Brooks et al., 2001, etc.).

To further confirm the claims by Vendler and Ioup, Aryawibawa (2014) investigated how children and adults assigned meanings to the universal quantifiers setiap/masingmasing 'each' and semua 'all' in Indonesian. His study involved 20 playgroup and kindergarten children at the Swadarma School (4-to-6-year old), 30 elementary students (1-6 graders) at the Bali Public Schools (7-to-12-year old), and 30 undergraduate students at the English Department, Universitas Udayana (17-to-22-year old). The results showed that across the boards, the use of semua "all" (Semua anak sedang membuat sebuah layang-layang "All children are 
making a kite", which should be appropriate to express the collective meaning described in Picture B is spread out to describe the distributive meaning indicated in Picture $\mathrm{C}$ below.

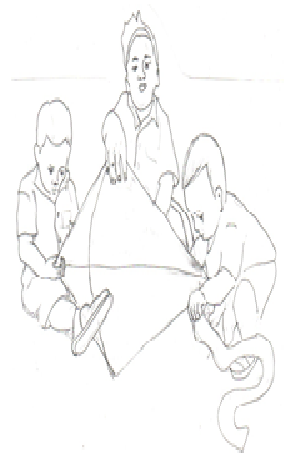

Picture B

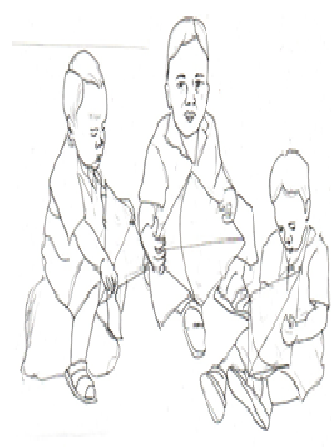

Picture C
Fig 1. Children are making a kite

Thus, the findings inform that only the canonical distributive meaning of masing-masing "each" was highly assigned by both the older children and adults, not the canonical collective meaning for semua "all". To summarize, referring to this finding, the claims made by Vendler and Ioup seems to not be confirmed (as taken from Aryawibawa, 2014).

The current study is motivated by Aryawibawa study's results (2014) just pointed out that is to further test if the universal quantifiers in Balinese is universally represented by Balinese speakers. The present study, however, just involved Balinese adults. The main purpose is to point out how Balinese adults assign meanings to the universal quantifiers in Balinese.

\section{METHOD}

\section{A. Data}

Current study deals with adults' representation of Balinese universal quantifiers. Therefore, data targeted for this study were expression (i.e., sentences) containing Balinese universal quantifiers such as sebilang 'each/every' and makejang 'all') such as sebilang anak cerike ento ngisi bal 'every child is carrying a ball', makejang anak cerike ento ngisi bal 'all the children are carrying a ball', ade anak cerik ah ukud ngisi bale konyang 'there is a child that is carrying all the balls'.

\section{B. Stimuli}

Picture selection tasks were used in this study. Stimuli included in this study consisted of a piece of paper containing three Balinese sentences with universal quantifiers in each of them (sebilang anak cerike ento ngisi bal 'every child is carrying a ball', makejang anak cerike ento ngisi bal 'all the children are carrying a ball', ade anak cerik ah ukud ngisi bale konyang 'there is a child that is carrying all the balls'), and of stimuli that consist of three different pictures depicting events with universal quantifiers. The stimuli with the pictures is shown below.

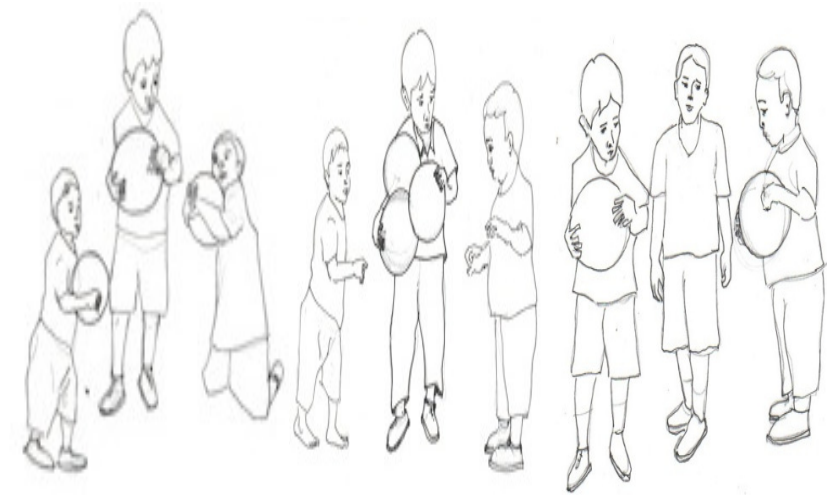

Picture A

Picture B

Picture C

\section{Participants}

Participants taking part in this study were thirty-seven Balinese undergraduate students at the Udayana University (M 19,0-20,0). They understand and speak Balinese fluently. They participated in current study voluntarily. Prior to the experiments, no explanation about the targeted knowledge was given to them.

\section{Experiment Procedure}

In general, methodologically the current study replicated the methods applied by Aryawibawa (2015). Each participant was given a piece of paper containing a list of sentences containing Balinese universal quantifiers (e.g. sebilang anak cerike ento ngisi bal 'every child is carrying a ball', makejang anak cerike ento ngisi bal 'all the children are carrying a ball') and a piece of paper having three pictures depicting events with universal quantifiers as illustrated in the stimuli section. In this task, they basically need to match each sentence with an appropriate picture. In this fashion, it is expected that their knowledge on the universal quantifiers is tapped. There was no time limitation to complete the task. It was expected that they worked on the task very carefully to obtain the subjects' true information on Balinese universal quantifiers.

\section{FINDINGS AND DISCUSSION}

The findings (fig. 3 ) show that $76 \%$ of the participants assigned canonical distributive and collective meanings to each/every and all respectively, while $24 \%$ of them assigned the meanings non-canonically (i.e., the collective meaning is represented to each/every, while the distributive meaning is represented to $a l l$ ). 


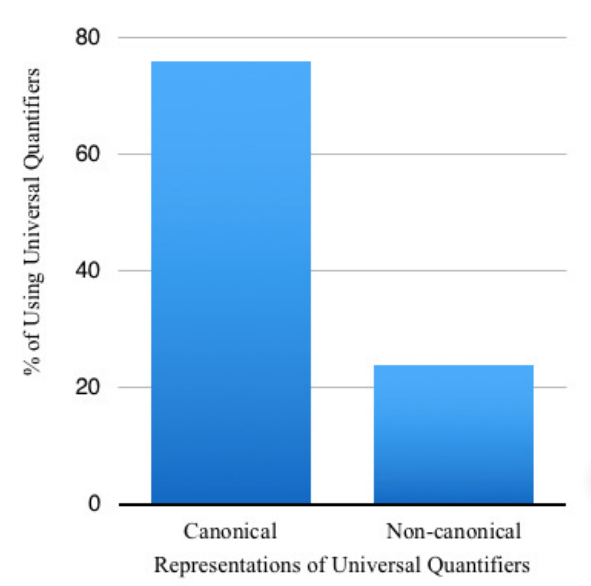

Fig 3. Adults' Representation of Balinese Universal Quantifiers

As summarized in Aryawibawa (2014) and stated at the outset of this paper, Vandler (1967) explains that the English universal quantifier all has the collective meaning in the sense that the predicate is applicable to all members of a group. For example, in All the children are riding a horse, the noun phrase (NP) the children is marked by the universal quantifier all and the predicate riding a (one same) horse is applicable to all the children. Thus, the meaning of the sentence is that all the children are riding the same horse. The universal quantifier each/every, in contrast to the collective meaning of all, has a distributive representation. To make it more specific, in the example Each child is riding a horse where the NP child is marked by the universal quantifier each and the predicate riding a horse applies to each child. In other words, the representation of each here entails that each child is riding a different horse. These canonical representations are also pointed out in other fourteen languages as pointed out by Ioup (1975) saying that the languages share the same representations of English all and each/every. This claim is further supported by other scholars such as Brooks and Braine (1996), Brooks et al., (2001).

The fact that the collective and distributive representations of all and each/every in English seems to be true as pointed out in the current study. Specifically, of thirty-seven of participants participating in this study, as shown in the findings, $76 \%$ of them can accurately assign both canonical collective and distributive meanings to all and each/every respectively. However, 24\% of them assign non-canonical representations to all and each/every. To put in different words, the collective meaning is represented to each/every, while the distributive meaning is represented to all.

The later figure seems to relate to the possible ambiguous nature of Balinese universal quantifiers. The potential ambiguity of Balinese universal quantifiers seems to be similar to that in Indonesian as pointed out by Aryawibawa (2014, 2015) showing that while $100 \%$ of the total 90 responses of the adults represented canonical meaning (i.e., distributive) to masing-masing 'each', for sетиa 'all', the representation of collective meaning is not so clear as that of masing-masing 'each'. Specifically, only almost $50 \%$ of their responses represented the canonical meaning (i.e., collective), $45 \%$ represented the non-canonical meaning (i.e., distributive) and about $5 \%$ represented the other meaning. Please bear in mind that it is just a potential in ambiguity between the collective and distributive meanings in Balinese. The fact (i.e. the figure) in this study, however, suggests that the two meanings (i.e. the collective and distributive meanings) are separated by the subjects.

Please also note that Balinese is unlike Indonesian. The later language shares an adverb bersama-sama together that is usually placed at the end of a sentence. As pointed out at the outset of the current paper that when a test was conducted by involving the adverb in a sentence using the universal quantifier semua 'all' in Indonesian the Indonesian adults can assign the canonical meaning (i.e. the collective meaning) to semua as also specifically pointed out in Aryawibawa (2014) saying that to find out that the use of semua "all" has a collective meaning, a further test was administered. In the test, a sentence using the quantifier semua "all" and a scope adverb bersama-sama "together" that occurs at the end of a sentence (Semua anak sedang makan sepotong ayam bersama-sama "All the children are eating a piece of chicken together") describing the following stimuli was used. The word bersamasama is to promote the collective meaning.

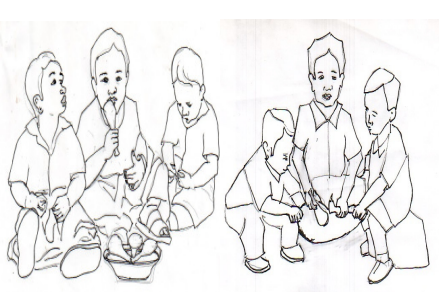

Picture A.

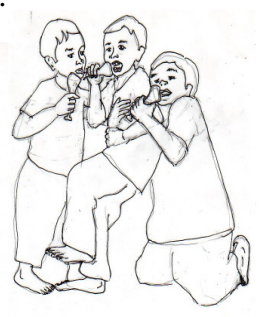

Picture C
Fig 4. Children are eating chicken

The experiment indicates that the use of bersama-sama "together" does not show the collective effect for the younger and older children. However, it does affect the adults.

The question is, how to account for the facts that the subjects do not assign the canonical collective meaning to semua? The explanation from Brooks and Braine (1996, as summarized in Aryawibawa, 2014) might be relevant to state here. Their explanation says that the sentence Semua anak sedang membuat sebuah layang-layang "All the children are making a kite" is ambiguous in the sense how many kites are being made. Specifically, if we look at the syntactic position of semua "all" and the noun sebuah layang-layang "a kite", it means that there is more than one kite that is being made by the children (the distributive meaning is inferred). However, if we look at the semantics or lexical features of semua "all", we can infer that there is only one kite that is being made (the collective meaning is inferred). Thus, the explanation seems to be relevant to explain the inability of the subjects to assign the canonical collective meaning to semua "all". 
The evidence seems also to be related to the fact that that the subjects, in particular the child subjects, are still in the learning process to be able to use the universal quantifiers in Indonesian. Specifically, the child subjects might need some time until the linguistic knowledge of the quantifiers matures in their mind. Put another way, in this context, developmental maturation seems to limit the child subjects' ability to practice the universal quantifiers in Indonesian. When the linguistic knowledge of the universal quantifiers is in a simple state they seem not to be able to separate the collective meanings from the distributive ones.

The other possible explanation might be related to the fact that the child subjects lack of exposure to Indonesian. They might use in school, but in other domains such as home, market, etc. they use other languages such as Balinese. Thus, exposure to a certain language is also perhaps to limit children's ability to use quantifiers in the language.

The other factor that might be worth looking at is children's sociolinguistic knowledge. More specifically, what we need to look at is whether the children participating in the study are monolingual (i.e. speaking only Balinese) or bilingual (i.e. speaking both Balinese and Indonesian fluently). If they are Balinese monolinguals, and please recall that Balinese does not share the adverb bersama-sama 'together', thus the use of the adverb does not influence their distinguishing the collective from distributive meanings since the Balinese quantifier influence. If, however, they are bilinguals the results should have been various. Given the evidence, it seems the former is the case. However, this needs to be tested specifically in future research.

How do the factors just pointed out work to affect the child subjects to use the universal quantifiers? It is perhaps that they are altogether influencing the process of comprehension and production of the quantifiers.

In Balinese, such an adverb is absent. Nevertheless, unlike the Indonesian adult subjects, the adult subjects in the present study can assign the collective meaning to makejang 'all' in Balinese. However, the findings need further testing in children. The study how children acquire the universal quantifiers in Balinese is imperative to further confirm the current findings.

\section{CONCLUSION}

The current study indicates that the canonical representations of the universal quantifier makejang 'all' and sebilang 'each/every' seem to share the same canonical representations of English universal quantifiers. More concretely, the adult subjects can separate sebilang anak cerike ento ngisi bal 'every child is carrying a ball' from makejang anak cerike ento ngisi bal 'all the children are carrying a ball'. The findings, however, are different from those in Indonesian in particular in using the collective quantifier semua 'all'. The difference is perhaps related to the ambiguity between the collective and distributive quantifiers in Indonesian.

This study, however, is still at a preliminary stage. In the next stage, the study needs further testing on how children acquire the representations as the ones shown by Balinese adults. In this fashion, it is expected that we will have a more comprehensive findings.

Referring to the discussion on the child results in the study of Indonesian universal quantifiers explained in the discussion section, in the follow up study it needs to be paying attention to the bilingualism aspect of the subjects in order to be able to interpret the results specifically. It is expected that in that fashion, a more confirm and comprehensive findings will be obtained.

The sociolinguistic aspect (e.g. the use of Balinese or other language by children) should also be given attention. Specifically, the study needs to identify whether the language or the other language such as Indonesian is used only at home or at other domains such as schools, market, play grounds, etc. in order to find out how the language influences the results.

\section{Acknowledgment}

I would like to acknowledge Dewa Diasana Putra for assisting me create the pictures used in the stimuli.

\section{References}

Aryawibawa, I. N., Ida Bagus Putra Yadnya, I Gusti Ngurah Parthama, Clifton. L. Pye. (2018).

Balinese Spatial Reference Frames: Some Linguistic and Non-linguistic Evidence From A Deaf Village in the North of Bali. Lingua (submitted 2018 and resubmitted the revised version 2018).

Aryawibawa, I. N. (2015). Quantifier Spreading of Setiap/Masing-masing in Indonesian: A Preliminary Analysis in the Lingual Journal, Universitas Udayana.

Aryawibawa, I. N. (2014). The Acquisition of Universal Quantifiers in Indonesian: A Preliminary Report in the proceeding of LAMAS Conference at Universitas Diponogoro.

Aryawibawa, I. N. (2010). 'Spatial Reference in Rongga, Balinese, and Indonesian'. Ph.D. Thesis. The University of Kansas.

Boroditsky, L. 2011. How Language Shapes Thought: The Languages we speak affect our perceptions of the world. Scientific American, 63-65.

Brooks, P. J. and M. D. S. Braine, G. Jia \& M. da G. Dias (2001). Early representation for all, each, and their counterparts in Mandarain Chinese and Portuguese. In Language Acquisition and Conceptual Development, M. Bowerman and S. C. Levinson (ed.), Cambridge: Cambridge University Press. 
Brooks, P. J. and M. D. S. Braine (1996). What Do Children Know about the Universal Quantifiers all and each? Cognition 60: 235-268.

Ioup, G. (1975). Some Universal for Quantifier Scope. Syntax and Semantics 4: 37-58. Philip, W. C. H. (1994). Event Quantification in the Acquisition of Universal Quantification. ProQuest Dissertations and Theses.

Vendler, Z. (1967). Linguistics in Philosophy. Ithaca: Cornell University Press. 